\title{
An on-farm rotational grazing trial: restricting access time to pasture did not affect the productivity of a dairy sheep flock in spring
}

\author{
Alberto Mantino, ${ }^{1}$ Alice Cappucci, ${ }^{2}$ Francesco Annecchini, ${ }^{1}$ Iride Volpi, ${ }^{1}$ Enrico Bargagli, ${ }^{3}$ \\ Enrico Bonari, ${ }^{1}$ Giorgio Ragaglini, ${ }^{1}$ Marcello Mele ${ }^{2,4}$ \\ ${ }^{1}$ Institute of Life Sciences, Sant'Anna School of Advanced Studies, Pisa; ${ }^{2}$ Centre for Agri-environmental \\ Research "Enrico Avanzi", University of Pisa, Pisa; ${ }^{3}$ Azienda Agricola Enrico Bargagli, Manciano (GR); \\ ${ }^{4}$ Department of Agriculture, Food and Environment, University of Pisa, Pisa, Italy
}

\section{Highlights}

- The challenge lies in comparing data of dairy sheep productivity collected at real farm condition with previous data measured in Mediterranean research stations.

- In this study, no difference in milk production was found between ewes allowed to graze two hours and four hours per day in spring.

- The ewes' herbage intake rate correlates positively with pasture quality and a mixed pasture with a high share of legumes led to a high intake rate.

- We believe that the outcomes in this manuscript can contribute to increase knowledge about the sustainable management of small ruminant dairy farms in the contest of rural areas.

\begin{abstract}
In the Mediterranean area, semi-extensive mixed farming systems characterise the inland landscape and guarantee the maintenance of several agroecosystem services. Rationed and rotational
\end{abstract}

Correspondence: Alberto Mantino, Institute of Life Sciences, Sant'Anna School of Advanced Studies, Piazza Martiri della Libertà 33, 56127 Pisa, Italy.

E-mail: alberto.mantino@santannapisa.it

Key words: Ewe; forage; mixed farming; Mediterranean; sustainable livestock production; agroecological practices; mixture; participatory research; co-design.

Acknowledgements and funding: this on-farm trial was funded by the STILNOVO project co-funded by the Tuscany Region within the Rural Development Programme 2014-2020, sub-measure 16.2 - grant number 726469.

Conflict of interests: the authors declare no potential conflict of interests.

Data availability: data supporting the findings of this study are available on Zenodo open access repository: https://doi.org/10.5281/ zenodo.3878177.

Received for publication: 27 July 2020.

Revision received: 18 September 2020.

Accepted for publication: 6 October 2020.

(C) Copyright: the Author(s), 2021

Licensee PAGEPress, Italy

Italian Journal of Agronomy 2021; 16:1711

doi:10.4081/ija.2020.1711

This article is distributed under the terms of the Creative Commons Attribution Noncommercial License (by-nc 4.0) which permits any noncommercial use, distribution, and reproduction in any medium, provided the original author(s) and source are credited. grazing have been proposed as efficient agroecological practices for sustainable intensification. Previous studies have highlighted that, during spring, restricted access time to pasture of below four hours per day decreases herbage intake and milk production of rotationally stoked ewes. The aim of this study was to assess the effect of restricted access time on daily herbage intake and milk productivity of Sarda ewes under rotational grazing management in a real farm located in southern Tuscany. The entire flock of 145 lactating ewes was allotted two homogenous groups and rotationally stoked on a grass-legume mixed pasture and fed about $1.7 \mathrm{~kg}$ of $\mathrm{DM}$ ewe $\mathrm{e}^{-1} \mathrm{~d}^{-1}$ of supplementation. Each group was then assigned to the following treatments: two hours per day of access time to pasture, from 10:00 to 12:00 CET, and four hours per day of access time to pasture, from 10:00 to 14:00 CET. Data on herbage yield and quality, dry matter intake and milk yield were collected from April 5 to May 10, 2018. The rotational grazing schedule was conducted allowing for abundant herbage and exploiting high-nutritive biomass of the upper horizon sward. The results of our on-farm experiment showed that restricting daily access time to pasture down two hours did not reduce the potential daily herbage intake and the milk performance of dairy ewes rotationally stocked on a mixed pasture in spring. Our study also highlighted the capacity of ewes to self-regulate the herbage intake in order to meet their energy requirements, when neutral detergent fibre is not a limiting factor. Our outcomes should encourage researchers and farmers to co-design further on-farm experiments.

\section{Introduction}

The global consumption of animal products is increasing and sustainable livestock systems are required to reduce environmental impacts linked to animal husbandry. Mixed and integrated crop-livestock farming systems seem to be suitable for the transition towards more sustainable animal productions owing to: i) crop diversification, integrating temporary grassland in arable crop rotations; ii) crop residue utilisation by animals; and iii) bet- 
ter animal welfare (Peyraud et al., 2014).

At the global level, in grassland-based livestock farming systems, the improvement in pasture availability through the increase in herbage production and its utilisation efficiency can significantly reduce the conflict between feed and food productions, thus reducing the use of products that are edible by humans in animal diets (Mottet et al., 2017). Rationed and rotational grazing have been proposed as efficient agroecological practices for the sustainable intensification of crop-livestock mixed farming systems (Wezel and Peeters, 2014), due to the enhancement of several ecosystem services in the agroecosystem, such as biodiversity conservation (Yao et al., 2019) and soil carbon stocking (Conant et al., 2017). Moreover, rotational grazing can positively affect the productivity of little ruminants: enhancing the bite mass of ewes at the start of the grazing in a new plot as reported by Penning et al. (1984) and increasing pasture nutritive value as showed by Marley et al. (2007) in a perennial ryegrass (Lolium perenne L.) pasture grazed by lambs.

In many Mediterranean areas, grassland-based farming systems characterise semi-extensive dairy farms, thereby conserving the soil (Vallebona et al., 2016), and preserving the landscape and cultural heritage (Oteros-Rozas et al., 2018). This can result in higher farm incomes even in marginal rural areas (Pulina et al., 2018). In these systems, livestock production is mainly based on dairy sheep farming for the transformation of milk into high-value products that are often protected and promoted by European Commission quality schemes, such as protected designation of origin (PDO) (Pulina et al., 2018). In fact, pasture-based feeding regimens allow the transfer, from fresh forage to milk and dairy products, of several compounds with aromatic characteristics and functional properties that are suitable for human health (Mele, 2009; Avondo et al., 2013).

However, several factors currently undermine the economic sustainability of pasture-based dairy systems. The volatility of the price of ewe milk on the international market, the increasing effort to protect against wolf predation (Zingaro et al., 2018) along with the low investment in innovation, efficient breeding programs and in-farm technical support are drastically limiting the competitiveness and the growth of semi-extensive dairy farms (Pulina et al., 2018).

In semi-extensive sheep dairy farms, the optimum milk productivity should be targeted through the combined management of pastures (e.g. allowance and species composition) and animals (e.g. race, flock composition, and grazing attitude), as they are key to rational feeding. In Mediterranean areas, the efficient management of sheep flocks should be based on rationed grazing, according to the season: i) continuous or rotational grazing with a low stocking rate in autumn and winter; and ii) high stocking rate rotational grazing in the spring when the daily accumulation of pasture biomass is higher. Hay and concentrates should be supplemented for grazing sheep especially when pasture is scarce (Molle et al., 2008). However, in the spring, the season with the highest availability of herbage, the efficient use of pasture resources can lead to an enhancement in pasture yield and fodder stocks. In fact, Di Grigoli et al. (2012) showed that rotational grazing management obtained a higher production of herbage biomass compared to continuous stocking, while no effects of grazing management were found on ewes' milk productivity and quality.

Grazing is a time-limited process with a circadian rhythm resulting from the interaction between the herbivore and sward characteristics, and the milk productivity of pasture-fed animals is affected by the voluntary dry-matter intake of herbage (Baumont et al., 2004). Few studies have investigated part-time grazing in
Mediterranean environments and the effect of access time of dairy sheep to pasture on milk production. The herbage intake of lactating ewes under part-time grazing can be affected by limiting access time to pasture and the quality of pasture (e.g., species composition and vegetation stage) (Molle et al., 2014; 2017, Valenti et al., 2017). Fodder supplementation in ewes' diet is another driver that affects the daily herbage intake of sheep (Molle et al., 2008).

De Renobales et al. (2012) measured the increase in daily herbage intake according to the reduction in alfalfa hay in the animals' diet, studying Latxa ewes stocked on a mixed pasture. Studying animals fed only with pasture resources, Bonanno et al. (2016) highlighted that prolonging daily grazing from $8 \mathrm{~h}$ to $22 \mathrm{~h}$ improved ewes' productive response in both grass and legumebased pastures. Studies carried out in the Mediterranean areas, have shown the different effects of daily grazing time on milk quality. Ewes' milk quality in terms of protein and fat content showed typical dilution patterns, the milk quality correlating negatively with the milk yield (Molle et al., 2014; 2017). Bonanno et al. (2016) showed that access time to pasture did not affect the fat content of ewes' milk, while the protein concentration decreased along with the decrease of access time, passing from $22 \mathrm{~h}$ to $8 \mathrm{~h}$ per day on ryegrass pasture. Valenti et al. (2017) showed that there was no effect of access time to pasture on fat and protein milk content. The diffusion of rationed and rotational grazing in the Mediterranean is still limited, despite the literature encouraging its adoption as a possible solution to increase pasture and animal productivity. In fact, farmers show scare interest in rationed and rotational grazing, believing that limited daily grazing time and surface would have detrimental effects on the ewes' intake and milk production, while could increase labour and equipment costs in terms of grazing fencing.

There is thus an urgent need to move from experimental farm conditions to real farm experiences in order to: i) tackle the farmers' perceptions regarding part-time grazing and rotational stocking; ii) assess tailored solutions in real farming contexts; and iii) to boost sustainable agroecological practices among dairy farmers.

As part of the activities of the STILNOVO project (Sub-measure 16.2 - Rural Development Plan of Tuscany Region 20142020), a co-designed and co-conducted experiment was therefore carried out in Southern Tuscany. The aim was to evaluate the introduction of part-time rotational grazing on a real dairy sheep farm, comparing the effect of two and four grazing hours per day on the daily herbage intake and the ewe milk productivity in the spring.

\section{Materials and methods}

\section{Experimental site}

The trial was conducted on a dairy sheep farm belonging to Enrico Bargagli located in Manciano, in southern Tuscany, Italy (42 $35^{\prime} 06.8^{\prime \prime N} 11^{\circ} 23$ '20'E, $32 \mathrm{~m}$ a.s.1.), from April 5 to May 10 2018. The climate of the area is Mediterranean with an average annual rainfall of $837 \mathrm{~mm}$ (2003-2018) and average annual temperature of $14.5^{\circ} \mathrm{C}(2003-2018)$. In the two months before the start of the experiment, February and March 2018, the rainfall amounted to $87 \mathrm{~mm}$ and $98 \mathrm{~mm}$, respectively. During the five weeks of the experiment, the total rainfall was $58 \mathrm{~mm}$, with eight days of rainfall. In the study period, the average daily temperature was $16^{\circ} \mathrm{C}$, with daily thermal excursion averaging $12^{\circ} \mathrm{C}$. Maximum temperature picked $28^{\circ} \mathrm{C}$ on April the $28^{\text {th }}$, while the lowest minimum temperature of $6^{\circ} \mathrm{C}$ occurred on April the $4^{\text {th }}$. 


\section{Pasture plots and experimental design}

The surface of the entire experimental area was approximately 1.9 ha, located in a uniform terrain with an average slope of $8 \%$ and north-west orientation $\left(280^{\circ}\right)$ (Figure 1). The soil was clayloam with sub-acid $\mathrm{pH}\left(6.35-\mathrm{H}_{2} \mathrm{O}, 1: 2.5\right), 1.35 \%$ of organic matter content (Walkley-Black method), $1.21 \mathrm{~g} \mathrm{~kg}^{-1}$ of total $\mathrm{N}$ content (Kjeldhal method), $224 \mathrm{ppm}$ of available $\mathrm{P}$ (as $\mathrm{P}_{2} \mathrm{O}_{5}$, Olsen method), $761 \mathrm{ppm}$ of exchangeable $\mathrm{K}$ (as $\mathrm{K}_{2} \mathrm{O}, \mathrm{BaCl}_{2}$ method).

The trial was carried out on an annual mixed pasture according to the widest pasture management system of the area (Vallebona $e t$ al., 2016). The grass-legume mixture was sown in November, after a minimum tillage, with the following species composition (seed rate): Avena byzantina L. (42 $\left.\mathrm{kg} \mathrm{ha}^{-1}\right)$, Avena sativa L. $\left(42 \mathrm{~kg} \mathrm{ha}^{-1}\right)$, Vicia sativa $\mathrm{L}$. $\left(21 \mathrm{~kg} \mathrm{ha}^{-1}\right)$, Trifolium alexandrinum L. $\left(21 \mathrm{~kg} \mathrm{ha}^{-1}\right)$, Trifolium incarnatum L. $\left(11 \mathrm{~kg} \mathrm{ha}^{-1}\right)$ and Trifolium resupinatum $\mathrm{L}$. $\left(5 \mathrm{~kg} \mathrm{ha}^{-1}\right)$. Before sowing, a mineral fertilisation was carried out with $50 \mathrm{~kg} \mathrm{ha}^{-1}$ of $\mathrm{P}_{2} \mathrm{O}_{5}$ and $25 \mathrm{~kg} \mathrm{ha}^{-1}$ of $\mathrm{K}_{2} \mathrm{O}$. No fertilisers were applied after sowing. During February and March 2018, the entire farm flock was allowed to graze down to standardise the biomass and height of the swards.

Two homogenous ewe groups were assigned to the following treatments: $2 \mathrm{H}$ access time to pasture of $2 \mathrm{~h} \mathrm{~d}^{-1}$, from 10:00 to 12:00 Central European Time (CET) and $4 \mathrm{H}$ access time to pasture of $4 \mathrm{~h} \mathrm{~d}^{-1}$, from 10:00 to 14:00 CET.

The rotational grazing was designed allowing to the ewe groups a high availability of pasture and the full exploitation of herbage nutritive value by varying the duration (number of days) of the grazing period (GP). On April 4, the experimental field was split into four paddocks of $4500 \mathrm{~m}^{2}$ each separated by electric fences. The allocation of treatment groups in each paddock and extra-paddock, and the duration of each GP are reported in Table 1. The reduction of the stocking period over GPs was planned by the researchers and the farmer, in order to allow the full exploitation of the pasture horizon with the highest nutritive value. Therefore, the pasture management was based on the actual conditions of the sward according to the grazing activity, in order to: i) compensate for the pasture senescence due to the negative effect of ewes' trampling; and ii) enable the reproductive parts of the plants to be eaten, thus inducing the regrowth of more nutritive plant organs, such as leaves.

\section{Animals}

The study was conducted using the Sarda breed, which is the most common specialised dairy breed in Italy representing about $80 \%$ of Italian dairy ewes (Pulina et al., 2018). All farming procedures followed the Directive 98/58/EC concerning the protection of animals kept for farming purposes. The research did not involve any animal experiments and thus, no ethical approval was necessary. Before separating the two groups into the pasture allotments, the animals were familiarised with the equipment and routines described below. On April 2, the entire flock of 145 lactating Sarda ewes was split into two homogeneous groups $(2 \mathrm{H}=73$ lactating ewes and $4 \mathrm{H}=72$ lactating ewes) according to the group composition, its productivity rate and lactating time. The lactating ewes of both group were composed as follow: $74 \%$ mature (more than 2 years old), $13 \%$ two years old, and $13 \%$ one year old (born in 2017). Ewes' composition of both group according to lactation stage was: $44 \%$ late lactation, $35 \%$ mid lactation, and $21 \%$ earlylactation. Each treatment group included also two non-lactating mature ewes, six milk lambs and one ram. All lacting ewes were machine-milked twice daily at 07:00 and 17:00 CET. The milk production per ewe was calculated dividing the group production by
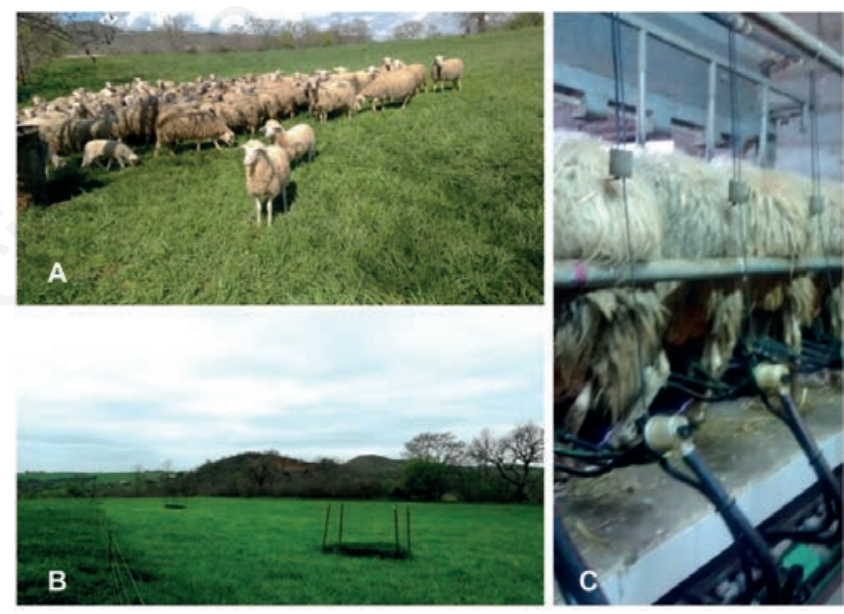

Figure 1. A) One of the two investigated ewe groups; B) the pasture plots; and $\mathrm{C}$ ) daily milking. (Photo credits: A: Alice Cappucci, B, C: Alberto Mantino).

Table 1. Paddock and extra-paddock grazing periods of ewes' groups treated with two hours (2H) and four hours (4H) of access time to pasture.

\begin{tabular}{|c|c|c|c|c|c|}
\hline & \multicolumn{4}{|c|}{ Paddock } & \multirow[t]{2}{*}{ Extra paddock } \\
\hline GP & A & B & C & D & \\
\hline GP1 06/04/2018 - 11/04/18 & $2 \mathrm{H}$ & & $4 \mathrm{H}$ & & \\
\hline GP2 12/04/2018 - 17/04/18 & & $4 \mathrm{H}$ & & $2 \mathrm{H}$ & \\
\hline $18 / 04 / 18-19 / 04 / 18$ & & & & & $2 \mathrm{H}$ and $4 \mathrm{H}$ \\
\hline GP3 20/04/2018 - 24/04/18 & $4 \mathrm{H}$ & & $2 \mathrm{H}$ & & \\
\hline GP4 25/04/2018 - 29/04/18 & & $2 \mathrm{H}$ & & $4 \mathrm{H}$ & \\
\hline $30 / 04 / 18-05 / 05 / 18$ & & & & & $2 \mathrm{H}$ and $4 \mathrm{H}$ \\
\hline GP5 06/05/2018 - 08/05/18 & $2 \mathrm{H}$ & & $4 \mathrm{H}$ & & \\
\hline GP6 09/05/2018 - 11/05/18 & & $4 \mathrm{H}$ & & $2 \mathrm{H}$ & \\
\hline
\end{tabular}


the actually ewes milked in each day.

Measured values of milk productivity parameters, made the day before experiment start, showed, for $2 \mathrm{H}$ and $4 \mathrm{H}$, respectively, that: milk yield was 1387 vs $1285 \mathrm{~g}$ ewe $^{-1} \mathrm{~d}^{-1}$, fat and protein corrected milk yield (FPCM) was 1259 vs $1213 \mathrm{~g} \mathrm{ewe}^{-1} \mathrm{~d}^{-1}$, fat yield was 79.0 vs $77.3 \mathrm{~g} \mathrm{ewe}^{-1} \mathrm{~d}^{-1}$, protein yield was 69.0 vs $67.1 \mathrm{~g} \mathrm{ewe}^{-1}$ $\mathrm{d}^{-1}$, casein yield was 55.0 vs $53.7 \mathrm{~g} \mathrm{ewe}^{-1} \mathrm{~d}^{-1}$, lactose yield was 67.7 vs $62.5 \mathrm{~g} \mathrm{ewe}^{-1} \mathrm{~d}^{-1}$, urea content was 34.5 vs $37.7 \mathrm{mg} 100$ $\mathrm{mL}^{-1}$, and somatic cell was 1838 vs $106810^{3} \mathrm{~mL}^{-1}$.

Both groups were supplemented with: $420 \mathrm{~g} \mathrm{DM} \mathrm{ewe}^{-1} \mathrm{~d}^{-1}$ of concentrate split into two meals at milking, $130 \mathrm{~g} \mathrm{DM} \mathrm{ewe}^{-1} \mathrm{~d}^{-1}$ of fava bean seeds, $130 \mathrm{~g} \mathrm{DM}$ ewe $\mathrm{e}^{-1} \mathrm{~d}^{-1}$ of corn seeds, $30 \mathrm{~g} \mathrm{DM}$ ewe $\mathrm{e}^{-1}$ $\mathrm{d}^{-1}$ of extruded linseed, $30 \mathrm{~g}$ DM ewe $\mathrm{e}^{-1} \mathrm{~d}^{-1}$ of soybean oil, $200 \mathrm{~g}$ DM ewe $\mathrm{e}^{-1} \mathrm{~d}^{-1}$ of sugar beet pulp before grazing, $300 \mathrm{~g} \mathrm{DM}$ ewe $\mathrm{e}^{-1}$ $\mathrm{d}^{-1}$ of wheat straw after grazing and $440 \mathrm{~g} \mathrm{DM}$ ewe $\mathrm{e}^{-1} \mathrm{~d}^{-1}$ of a alfalfa hay overnight. Animals had continuous access to water. When animal groups were not on pasture, they were kept in two separate enclosures or, indoors, in two separate parts of the stable. Every day, the farmer and a member of the research staff verified the usage level of supplementation dose and the lack of orts.

\section{Data collection}

Before each GP, the pre-grazing herbage mass was sampled in six replicates per paddock by cutting areas of $0.25 \mathrm{~m}^{2}$ at a stubble height of $0.03 \mathrm{~m}$. At the end of each GP, post-grazing herbage mass was estimated by cutting six replicates of $0.25 \mathrm{~m}^{2}$ per paddock at a stubble height of $0.03 \mathrm{~m}$. In each paddock, three exclusion cages, one meter long and one meter wide, were maintained in order to measure the herbage potential growth from the beginning to the end of each GP, when the biomass was collected by cutting an area of $0.25 \mathrm{~m}^{2}$ at a stubble height of $0.03 \mathrm{~m}$. Herbage sampling was conducted in three representative areas of each paddock. Pre- and post-grazing herbage mass was harvested two times in each area. Following the same layout, three exclusion cages were placed, according to the same layout, one each of the three sampling areas of the paddocks. Moreover, to reduce the sampling error, the harvest of the herbage mass samples was conducted by the same member of the research team during all the trial with a single-handed reaping-hook. All biomass samples were separated into grass, legumes and forbs, weighed as fresh and then oven-dried at $60^{\circ} \mathrm{C}$ until constant weight for dry matter (DM) determination, in order to obtain both the overall herbage dry mass and the dry mass of the three herbage components. The computation of daily herbage growth (DHG) was calculated subtracting the average values of the two pre-grazing herbage mass of the same zone from the herbage mass value of the proximal exclusion cage, as follow:

$$
\text { DHG }\left[g^{-2} d^{-1}\right]=\frac{\left(\text { ECHM }\left[\mathrm{g} \mathrm{m}^{-2}\right]-\operatorname{PreHM}\left[\mathrm{g} \mathrm{m}^{-2}\right]\right)}{\mathrm{D}(d)}
$$

where ECHM is the exclusion cage herbage mass, PreHM is the pre-grazing herbage mass, and $\mathrm{D}$ is the grazing period duration in days $(d)$.

The potential daily herbage allowance (HeA) per ewe was calculated as:

$$
\text { DHG }\left[g^{-2} d^{-1}\right]=\frac{\left(\text { ECHM }\left[g^{-2}\right]-\operatorname{PreHM}\left[g^{-2}\right]\right)}{\mathrm{D}(d)}
$$

where, $\mathrm{A}$ is the paddock surface area, and $\mathrm{E}$ is the number of heads (h) per group (lactating and non-lactating ewes and mutton, excluding lambs) (Sollenberger et al., 2005).

Dried subsamples of each replicate of pre-grazing herbage mass and post-grazing herbage mass were analysed for the organic matter concentration by ashing at $550^{\circ} \mathrm{C}$ for $5 \mathrm{~h}$ in a muffle furnace. Crude protein content $(\mathrm{CP})(\mathrm{N} \times 6.25)$ and crude fat was assessed with the AOAC method (1990). The concentrations of ash-free neutral detergent fibre (NDF), ash-free acid detergent fibre (ADF), and acid detergent lignin (ADL), were measured according to Van Soest et al. (1991). Net energy (NE) content of pre-grazing herbage mass and post-grazing herbage mass were calculated from their chemical composition according to INRA (2010).

Group milk production was measured and one bulk sample was collected twice per day, at each milking (twice per day), every day per treatment group $(2 \mathrm{H}$ and $4 \mathrm{H})$. Subsequently, milk samples were processed to evaluate protein, fat, casein, lactose and urea content by Milkoscan 6000 FT (Foss Electric, Hillerød Denmark). Somatic cell count (SCC) was also carried out according to ISO 13366-2/IDF 148-2 (ISO-IDF, 2006), by Fossmatic 5000 (Foss Electric).

Daily milk yield was calculated by adding night and morning milking values. Fat and protein corrected milk (FPCM) was calculated as reported by Pulina et al. (2005):

$\operatorname{FPCM}[g]=\mathrm{L}[g](0.25+0.085 \mathrm{~F}[\%]+0.035 \mathrm{P}[\%])$

where FCPM is the fat and protein corrected milk (g), with 6.5 and $5.8 \%$ of content respectively, $\mathrm{L}$ is the Milk yield, $\mathrm{F}$ is the milk fat content $(\%)$, and $\mathrm{P}$ is the milk protein content $(\%)$. The reference value of $\mathrm{kcal} \mathrm{kg}^{-1}$ is 1.047 .

In order to compare animal group data with single animal data collected in experimental trials conducted in the past years, the daily potential herbage intake per ewes (PHI) per each treatment group and GP was estimated as follow:

$$
\mathrm{PHI}\left[g D M^{-1} d^{-1}\right]=\frac{\left(\mathrm{ECHM}\left[\mathrm{g} \mathrm{m}^{-2}\right]-\mathrm{PostHM}\left[\mathrm{g} \mathrm{m}^{-2}\right]\right) \times A\left[\mathrm{~m}^{2}\right]}{\mathrm{D}(d) \times E[h]}
$$

where ECHM is the exclusion cage herbage mass, PostHM is the post-grazing herbage mass, $\mathrm{A}$ is the paddock surface area, D is the grazing period duration in days $(d)$ and $\mathrm{E}$ is the number of heads (h) per group (lactating and non-lactating ewes and mutton, excluding lambs).

The daily potential net energy intake per ewes (PNEI) was calculated for each treatment group and GPs multiplying the PHI with its NE content.

\section{Statistical analysis}

Statistical analysis was performed using R software (R Core Team, 2020). Pasture parameters, describing biomass production, utilisation and quality, were analysed in order to assess the differences in grazing access time (AT) and grazing period (GP). Bartlett's test was used to check the homogeneity of variance and the Shapiro-Wilk test to check the normality of residuals. Data transformation was not necessary. The effect of AT and GP was determined using the lme() function for linear mixed-effect models of the 'nlme' R package (Pinheiro et al., 2020), with factors AT $(n=2)$ and GP $(n=6)$ as fixed effects and paddocks $(n=4)$ as random effect.

Tukey's HSD post-hoc test was carried out by pairwise multiple comparisons using the 'emmeans' $\mathrm{R}$ package (Lenth et al., 
2020) with the emmeans() function. Pearson's correlation was performed to investigate the relationships between potential herbage intake and herbage allowance. The effect of access time to pasture on milk yield and quality was evaluated at the animal group level.
Thus, treatment comparison was performed by trend analysis of best-fitting regression model on milk yield characteristics and milk composition of the entire dataset with the emtrends() function using the 'emmeans' R package.

Table 2. Effect of access time and grazing period on pasture variables and potential herbage dry matter intake and potential herbage net energy intake ( \pm standard error).

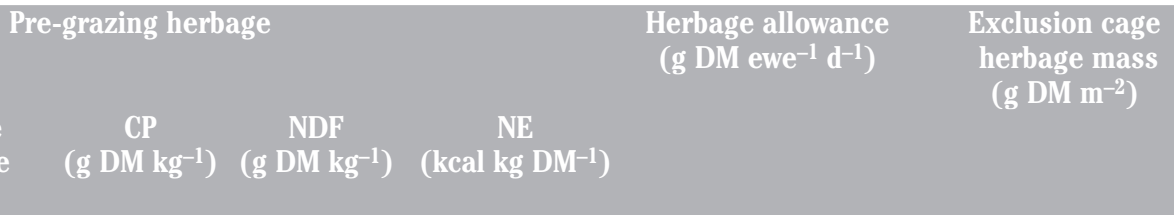

\begin{tabular}{|c|c|c|c|c|c|c|c|c|}
\hline Access & & & & & & & & \\
\hline $2 \mathrm{H}$ & & $267 \pm 19$ & $0.61 \pm 0.02$ & $183 \pm 5$ & $434 \pm 12$ & $1137 \pm 44$ & $4659 \pm 443$ & $322 \pm 14$ \\
\hline $4 \mathrm{H}$ & & $263 \pm 13$ & $0.60 \pm 0.02$ & $178 \pm 6$ & $426 \pm 16$ & $1166 \pm 47$ & $4710 \pm 366$ & $330 \pm 14$ \\
\hline Grazing & & & & & & & & \\
\hline GP1 & & $168 \pm 44^{c}$ & $0.59 \pm 0.04$ & $210 \pm 5^{\mathrm{a}}$ & $338 \pm 15^{\mathrm{d}}$ & $1449 \pm 27^{\mathrm{a}}$ & $2599 \pm 485^{\mathrm{d}}$ & $255 \pm 19 c$ \\
\hline GP2 & & $255 \pm 49^{b}$ & $0.61 \pm 0.05$ & $195 \pm 5^{\mathrm{a}}$ & $384 \pm 6^{\text {c }}$ & $1343 \pm 12^{b}$ & $3155 \pm 371^{\mathrm{cd}}$ & $309 \pm 15^{b c}$ \\
\hline GP3 & & $249 \pm 35^{b}$ & $0.69 \pm 0.02$ & $195 \pm 2^{\mathrm{a}}$ & $426 \pm 13^{b}$ & $1127 \pm 17^{c}$ & $4146 \pm 482^{b c}$ & $338 \pm 15^{\mathrm{ab}}$ \\
\hline GP4 & & $323 \pm 30^{\mathrm{ab}}$ & $0.65 \pm 0.03$ & $164 \pm 4^{b}$ & $471 \pm 5^{\mathrm{a}}$ & $1027 \pm 21^{d}$ & $4954 \pm 630^{\mathrm{b}}$ & $404 \pm 20^{a}$ \\
\hline GP5 & & $262 \pm 58^{\mathrm{ab}}$ & $0.56 \pm 0.06$ & $163 \pm 8^{b}$ & $472 \pm 8^{a}$ & $982 \pm 25^{d}$ & $6300 \pm 910^{a}$ & $309 \pm 18^{b c}$ \\
\hline GP6 & & $334 \pm 49^{a}$ & $0.54 \pm 0.03$ & $157 \pm 8^{b}$ & $489 \pm 9^{\mathrm{a}}$ & $982 \pm 37^{\mathrm{d}}$ & $6950 \pm 794^{\mathrm{a}}$ & $340 \pm 15^{\mathrm{ab}}$ \\
\hline P-value & df & & & & & & & \\
\hline AT X GP & 1 & 0.77 & 0.66 & 0.35 & 0.28 & 0.10 & 0.81 & 0.56 \\
\hline & 5 & $<0.0001$ & 0.08 & $<0.0001$ & $<0.0001$ & $<0.0001$ & $<0.0001$ & 0.0002 \\
\hline & 5 & 0.16 & 0.16 & 0.44 & 0.17 & 0.02 & 0.18 & 0.25 \\
\hline $\begin{array}{l}\text { Shapiro- } \\
\text { normality }\end{array}$ & & 0.90 & 0.84 & 0.05 & 0.11 & 0.57 & 0.70 & 0.32 \\
\hline
\end{tabular}

\begin{tabular}{|c|c|c|c|c|c|c|c|c|}
\hline & & \multicolumn{5}{|c|}{ Post-grazing herbage } & \multirow{2}{*}{$\begin{array}{c}\text { PHI } \\
\left(\mathrm{g} \mathrm{DM} \mathrm{ewe}^{-1} \mathrm{~d}^{-1}\right)\end{array}$} & \multirow{2}{*}{$\begin{array}{c}\text { PNEI } \\
\left.\text { (kcal ewe } \mathrm{e}^{-1} \mathrm{~d}^{-1}\right)\end{array}$} \\
\hline & & $\begin{array}{c}\text { Herbage } \\
\text { mass } \\
\left(\mathrm{g} \mathrm{DM} \mathrm{m}^{-2}\right)\end{array}$ & $\begin{array}{l}\text { Legume } \\
\text { presence } \\
(\%)\end{array}$ & $\begin{array}{c}\mathrm{CP} \\
\left(\mathrm{g} \mathrm{DM} \mathrm{kg}^{-1}\right)\end{array}$ & $\begin{array}{c}\text { NDF } \\
\left(\mathrm{g} \mathrm{DM} \mathrm{kg-1}^{-1}\right)\end{array}$ & $\begin{array}{c}\mathrm{NE} \\
\left(\mathrm{kcal} \mathrm{kg} \mathrm{DM}^{-1} \text { ) }\right.\end{array}$ & & \\
\hline \multicolumn{9}{|l|}{ Access time } \\
\hline $2 \mathrm{H}$ & & $247 \pm 15$ & $0.52 \pm 0.03$ & $147 \pm 5$ & $471 \pm 16$ & $984 \pm 47$ & $1033 \pm 89$ & $1051 \pm 73$ \\
\hline $4 \mathrm{H}$ & & $251 \pm 14$ & $0.50 \pm 0.04$ & $144 \pm 7$ & $481 \pm 16$ & $988 \pm 46$ & $1051 \pm 69$ & $1109 \pm 67$ \\
\hline \multicolumn{9}{|c|}{ Grazing period } \\
\hline GP1 & & $176 \pm 20^{\mathrm{b}}$ & $0.52 \pm 0.04$ & $170 \pm 5^{\mathrm{a}}$ & $393 \pm 11^{\mathrm{c}}$ & $1312 \pm 19^{a}$ & $777 \pm 43^{\mathrm{b}}$ & $1072 \pm 62$ \\
\hline GP2 & & $234 \pm 25^{\mathrm{ab}}$ & $0.51 \pm 0.09$ & $161 \pm 12^{\mathrm{a}}$ & $451 \pm 18 \mathrm{bc}$ & $1018 \pm 34^{b}$ & $748 \pm 150^{\mathrm{b}}$ & $886 \pm 182$ \\
\hline GP3 & & $255 \pm 16^{\mathrm{ab}}$ & $0.61 \pm 0.05$ & $160 \pm 6^{\mathrm{a}}$ & $458 \pm 16^{\mathrm{bc}}$ & $1083 \pm 35^{b}$ & $999 \pm 144^{\mathrm{ab}}$ & $1114 \pm 175$ \\
\hline GP4 & & $313 \pm 23^{a}$ & $0.42 \pm 0.06$ & $121 \pm 7^{b}$ & $504 \pm 17^{\mathrm{ab}}$ & $861 \pm 37^{c}$ & $1088 \pm 38^{a b}$ & $1031 \pm 63$ \\
\hline GP5 & & $242 \pm 18^{a b}$ & $0.62 \pm 0.04$ & $147 \pm 8^{a b}$ & $496 \pm 31^{\mathrm{ab}}$ & $863 \pm 38 c$ & $1323 \pm 95^{\mathrm{a}}$ & $1214 \pm 78$ \\
\hline GP6 & & $274 \pm 18^{a}$ & $0.39 \pm 0.04$ & $116 \pm 7^{b}$ & $557 \pm 17^{\mathrm{a}}$ & $779 \pm 23^{c}$ & $1320 \pm 108^{a}$ & $1164 \pm 104$ \\
\hline P-value & df & & & & & & & \\
\hline \multirow[t]{3}{*}{ AT X GP } & 1 & 0.76 & 0.82 & 0.65 & 0.53 & 0.86 & 0.84 & 0.57 \\
\hline & 5 & 0.002 & 0.052 & $<0.0001$ & 0.000 & $<0.0001$ & 0.002 & 0.521 \\
\hline & 5 & 0.15 & 0.86 & 0.22 & 0.48 & 0.08 & 0.42 & 0.51 \\
\hline $\begin{array}{l}\text { Shapiro-Wilk } \\
\text { normality test }\end{array}$ & & 0.78 & 0.43 & 0.81 & 0.40 & 0.06 & 0.77 & 0.73 \\
\hline
\end{tabular}




\section{Results and discussion}

The study was carried out under rainfed conditions in a Mediterranean environment, and the aim was to evaluate tailored solutions for rotational grazing management in semi-extensive dairy sheep farming. The study was conducted on a real farm with 145 lactating Sarda sheep with the collaboration of the farmer. Before the rotational grazing trial, the treatment groups were allowed to graze separately in an annual ryegrass (Lolium multiflorum Lam. var. italicum) extra-paddock with an availability of about 1 ha of surface per group located $100 \mathrm{~m}$ away from the experimental field. In the reference period, mild climatic conditions were suited to animal grazing and favoured the growth and re-growth of pasture in each GP. However, the duration of the six GPs of the trial was reduced during the experiment, from 6 days in GP1 and GP2, to 5 in GP3 and GP4 and 3 in GP5 and GP6. The duration of GPs was shortened in order: i) to allow ewes to graze the most nutritious pasture horizon (upper); and ii) to not limit the potential ingestion of ewes in the case of a scarce availability of herbage biomass. Moreover, for the same reason between GP2 and GP3, and GP4 and GP5, groups were allowed to graze separately in the annual ryegrass extra-paddock for three and five days, respectively. Before and during the grazing trial and during the extra-paddock periods animals received the same amount of daily supplements.

\section{Pasture characteristics and potential herbage intake}

Statistical analysis of the pasture characteristics (mass and nutritive value) and animal herbage intake highlighted no significant differences between treated groups, $2 \mathrm{H}$ and $4 \mathrm{H}$ of access times to pasture. Conversely, significant differences were observed among GPs for all the evaluated parameters with the exception of PNEI and legume share in pre- and post-grazing herbage mass (Table 2).

The pre-grazing herbage mass significantly increased during the trial in line with the number of grazing days. The herbage mass in the paddocks did not limit the ewes' potential ingestion, yielding over $100 \mathrm{~g} \mathrm{DM} \mathrm{m}^{-2}$ when CP content was over $160 \mathrm{~g} \mathrm{~kg}^{-1} \mathrm{DM}$ and over $250 \mathrm{~kg} \mathrm{DM} \mathrm{m}^{-2}$ when CP was approximately $160 \mathrm{~g} \mathrm{~kg}^{-1} \mathrm{DM}$ (Avondo et al., 2002). According to the seasonal depletion in nutritive value, pre-grazing mass showed a significant decrease in NE over the experiment. In fact, in the pre-grazing, herbage NDF ranged from $338.3 \mathrm{~g} \mathrm{~kg}^{-1} \mathrm{DM}$ (R1) to $489.0 \mathrm{~g} \mathrm{~kg}^{-1} \mathrm{DM}$ (R6), while the $\mathrm{CP}$ content decreased from $209.8 \mathrm{~g} \mathrm{~kg}^{-1}$ (R1) to $157.3 \mathrm{~g} \mathrm{~kg}^{-1}$ DM (R6).

Similar NDF values were reported by Bonanno et al. (2016), who carried out a grazing trial in a similar environment (dry Mediterranean) and in the same season (from April to May) on sulla (Hedysarum coronarium L.) and annual ryegrass (Lolium multiflorum Lam.) pure pastures. The high values of CP in the pregrazing herbage mass recorded in our study are comparable with data reported in a rotational grazing trial conducted in Sardinia on a berseem clover (Trifolium alexandrinum L.) pasture in early spring (Molle et al., 2017), evidencing the high quality of our experimental mixed pasture. This result was also achieved due to the considerable amount of legumes in the pre-grazing herbage mass, which averaged about $61 \%$ with no significant differences among treatments and GPs (Table 2).

The post-grazing herbage mass varied significantly among GPs, from $176 \mathrm{~g} \mathrm{DM} \mathrm{m}^{-2}$ in GP1 to $313 \mathrm{~g} \mathrm{DM} \mathrm{m}^{-2}$ in GP4. According to pre-grazing herbage parameters, the results of handplucked samples of post-grazing herbage, showed a significant decrease in $\mathrm{CP}$ and NE content along the season, while NDF increased significantly according to the GP progression (Table 2). Pasture quality depletion was recorded in each GP and in particular, the reduction in NE content from pre-grazing to post-grazing herbage varied from 3.9 to $20.6 \%$ in GP3 and GP6, respectively. Although a decrease in nutritive value was recorded, in the postgrazing herbage mass, CP varied from 170 in GP1 to $116 \mathrm{~g} \mathrm{~kg}^{-1}$ DM in GP6 and NDF varied from 393 in GP1 to $557 \mathrm{~g} \mathrm{~kg}^{-1} \mathrm{DM}$ in GP6. These results show that after grazing, the pasture maintained a good nutritive value with an abundant presence of legumes (on average $51 \%$ of total dry mass).

Thus, based on post-grazing herbage mass quality values, it can be argued that the nutritive value of the paddocks did not limit the potential ingestion of ewes (Avondo et al., 2002). The potential herbage allowance (HeA) varied significantly among GPs, increasing from 2599 to $6950 \mathrm{~g} \mathrm{DM} \mathrm{ewe}^{-1} \mathrm{~d}^{-1}$, in GP1 and GP6, respectively, depending on the reduction in days of GPs. Similar data on herbage allowance were reported by Molle et al., (2017) in a study conducted in Sardinia on a legume pasture in spring.

Almost all analysed parameters of pasture quality as HeA did not significantly differ between $2 \mathrm{H}$ and $4 \mathrm{H}$ at beginning of each GP, despite they varied significantly among GPs (Table 2). PHI did not vary significantly among treatments $\left(1033\right.$ vs $1051 \mathrm{~g} \mathrm{DM} \mathrm{ewe}^{-1}$ $\mathrm{d}^{-1}$ of $2 \mathrm{H}$ and $4 \mathrm{H}$ respectively).. This result is not in agreement with previous studies on the ingestion of rotationally stocked Sarda ewes, carried out at animal level in experimental stations. Molle et al. (2014) showed that herbage intake of ewes, fed with about 1.4 $\mathrm{kg} \mathrm{DM}$ ewe $\mathrm{e}^{-1} \mathrm{~d}^{-1}$ of hay (700 g) and concentrate (700 g), decreased significantly (from $1059 \mathrm{~g} \mathrm{DM} \mathrm{ewe}^{-1} \mathrm{~d}^{-1}$ to $648 \mathrm{~g} \mathrm{DM} \mathrm{ewe}^{-1} \mathrm{~d}^{-1}$ ) moving from four to two hours of daily access time to a ryegrass pasture. Moreover, they concluded that limiting the grazing time to less than six hours per day constrained the herbage intake and also the milk production of Sarda dairy ewes, in fact herbage intake was equal to $1233 \mathrm{~g} \mathrm{DM}$ ewe $\mathrm{g}^{-1} \mathrm{~d}^{-1}$ allowing six hours per day of grazing. In a follow-up study, Molle et al., (2017) showed that in ewes fed on a high nutritive legume-based pasture supplemented with the same amounts of hay and concentrate (1400 g DM ewe $\left.\mathrm{g} \mathrm{d}^{-1}\right)$, the herbage intake decreased significantly (from $1782 \mathrm{~g} \mathrm{DM}^{\text {ewe }}{ }^{-1}$ $\mathrm{d}^{-1}$ to $1168 \mathrm{~g} \mathrm{DM}^{\mathrm{ew}} \mathrm{e}^{-1} \mathrm{~d}^{-1}$ ) moving from four to two hours of daily access time to pasture. Conversely, they found no difference between four and six hours per day of access time (herbage intake equal to $1723 \mathrm{~g} \mathrm{DM}$ ewe $\mathrm{e}^{-1} \mathrm{~d}^{-1}$ six hours per day of access to pasture).

There are several possible reasons for the lack of agreement between our results and Molle's: i) in our on-farm experiment, the simplified methodology carried out was able to estimate the potential herbage intake instead the ewe herbage intake measured by double-weighing technique (Penning and Hooper, 1985); ii) the different types of pasture, actual timing of access to pasture and stocking rate; iii) the different amounts of hay and concentrate in the ewes' daily diet and the type of supplement; and iv) finally the different scale adopted to evaluate the ewe herbage intake in response to treatment applied to large groups. Under the methodological point of view, the exclusion cages system for estimating the potential herbage intake can lead to bias, especially in field condition, where the pasture heterogeneity can be higher and because of the length of grazing period and consequent trampling effects. Nevertheless, this methodology allowed to manage the farm sheep flock according to real farm conditions, excluding the effect of disturbance due to more invasive sampling methods. However, our data are in line with data reported by Molle et al. in 2014 and in 2017 for four hour and two hours of pasture access time, respectively. 
Secondly, pasture composition affects herbage intake. Generally, grazing animals prefer clover, to which they usually exhibit a higher intake capacity compared to grass, and when clover and grass are well balanced, a higher intake has been observed, because consuming two or more foods together exceeds the averaged benefit of consuming the foods in isolation (Gregorini et al., 2017). In addition, in a homogeneous sward, a higher intake rate was observed when ewes grazed the top layer of the sward rather than the bottom (Prache et al., 1998). Thus the high quality of the pasture of our experiment, as well as its management, may have favoured animal intake in a shorter grazing time. As additional hypothesis, the different access time to the pasture of the two groups may have also favoured the $2 \mathrm{H}$ group that usually started grazing two hours later than $4 \mathrm{H}, 10: 00$ vs 8:00 CET, in the studies of Molle et al. (2014, 2017). Indeed, this difference can lead to a higher DM and water-soluble carbohydrates content in the pasture mass that can positively affect the herbage intake and the ruminal efficiency as reported by Avondo et al. (2008) for goats.

Lastly, in our experiment, supplementation accounted for 1700 g DM ewe $\mathrm{e}^{-1} \mathrm{~d}^{-1}$, while in cited studies this was at least $18 \%$ lower (1400 g DM ewe $\mathrm{g}^{-1} \mathrm{~d}^{-1}$ ). The herbage intake of ewes may thus be affected by the higher amount of supplementation, reducing the time necessary to reach the amount of herbage ingested daily. In fact, it has been demonstrated that in lactating ewes and goats, herbage intake is negatively related to hay and concentrate supplementation with specific substitution rates (Molle et al., 2008; De Renobales et al., 2012; Charpentier et al., 2019a).

Our results indicate that no more than two hours per day of access time to pasture are enough to satisfy the voluntary intake of lactating Sarda ewes in specific conditions, such as: i) the pasture management, reducing the grazing activity to the upper and highquality layer; ii) the high quality of the pasture, that is a consequence of the meteorological condition, and the management system as well; iii) the starting time of the daily grazing, that was postponed later in morning in $2 \mathrm{H}, 10: 00 \mathrm{CET}$, after the milking and the supplementation of the flock, that may increase the efficiency of the ingested herbage enhancing the rumen activity; iv) the high supplementation of hay and concentrate in order to guarantee a high level of milk yield and quality. Assessing the herbage intake of Comisana ewes with no feeding supplementation, Bonanno et al. (2016) highlighted that herbage intake increased by prolonging daily grazing from eight to twenty-two hours, in both grass and legume-based pastures. The authors also showed that ewe daily intake was higher when grazing sulla, a Mediterranean biennial legume (Borreani et al., 2003; Annicchiarico et al., 2014), than ryegrass with an herbage intake of 1341 and $1038 \mathrm{~g} \mathrm{DM} \mathrm{ewe}^{-1} \mathrm{~d}^{-1}$, respectively. Another study, conducted by Valenti et al. (2017) in Sicily (southern Italy) on Comisana ewes confirmed previous outcomes, highlighting that ewes fed with $500 \mathrm{~g} \mathrm{DM} \mathrm{ewe}^{-1} \mathrm{~d}^{-1}$ of supplements had a lower herbage intake (about $1000 \mathrm{~g} \mathrm{DM} \mathrm{ewe}^{-1} \mathrm{~d}^{-1}$ ) than that reported by Bonanno et al. in 2016. Furthermore, Valenti et al. (2017) showed that reducing grazing time from seven to four hours per day negatively affected herbage intake only in the case of low quality pasture.

In our experiment, PHI varied significantly among GPs and showed a positive correlation with herbage allowance $(0.63$ Pearson's $\mathrm{r}, \mathrm{P}<0.001)$ in accordance with Charpentier et al. (2019b) regarding Alpine goats grazing on a high-nutritive and abundant mixed pasture. This result is also consistent with a previous study on the effect of herbage allowance on ewes' herbage intake by Penning et al. (1986). Our results of total potential DM intake, herbage plus supplementation, are in line with data on intake prediction models for lactating ewes proposed by Avondo et al. (2002) and Pulina et al. (2013).

A particular outcome of our experiment is that the PNEI did not vary significantly among treatments and GPs, showing few variations during the experiment. Moreover, PNEI did not correlate with herbage allowance and pre-grazing herbage mass. This can be explained by the slight depletion in pasture quality from GP1 to GP6 and the increase in pasture allowance, due to the reduction of grazing days from GP1 to GP6.

The fact that PHI increased with GP progression while PNEI remained constant, could demonstrate the capacity of ewes to selfregulate the herbage intake in order to meet their daily energy requirements, adapting the daily herbage intake and ingestion rate in relation to the herbage energy content. In line with our findings, Sauvant et al. (1996) showed that the intake inhibition of ewes depends on satiation factors related to rumen load and energy supply. Garcia et al. (2003) also showed that ewes are able to modulate their daily grazing time to cover their needs when good pasture availability and high-nutritive value are guaranteed.

Our outcomes regarding PHI and PNEI are corroborated by the milk yield data shown in the following section.

Table 3. Average values (+standard error) of milk yield, components of milk yield, urea and somatic cell milk content of dairy ewes with two hours $(2 \mathrm{H})$ and four hours $(4 \mathrm{H})$ of access time to pasture during in each investigated grazing period.

\begin{tabular}{|c|c|c|c|c|c|c|c|c|}
\hline & $\begin{array}{l}\text { Milk yield } \\
\left(\mathrm{g}^{\mathrm{e}} \mathrm{ewe}^{-1} \mathrm{~d}^{-1}\right)\end{array}$ & $\begin{array}{l}\text { FPCM yield } \\
\left(\mathrm{g} \text { ewe } \mathrm{e}^{-1} \mathrm{~d}^{-1}\right)\end{array}$ & $\begin{array}{c}\text { Fat yield } \\
\left(\mathrm{g} \text { ewe } \mathrm{e}^{-1} \mathrm{~d}^{-1}\right)\end{array}$ & $\begin{array}{l}\text { Protein yield } \\
\left(g_{\text {g ewe }}^{-1} \mathbf{d}^{-1}\right)\end{array}$ & $\begin{array}{l}\text { Casein yield } \\
\left(\mathrm{g}_{\mathrm{ewe}}^{-1} \mathrm{~d}^{-1}\right)\end{array}$ & $\begin{array}{l}\text { Lactose yield } \\
\left(\mathrm{g} \text { ewe } \mathrm{e}^{-1} \mathrm{~d}^{-1}\right)\end{array}$ & $\begin{array}{l}\text { Urea content } \\
\left(\mathrm{mg} 100 \mathrm{~mL}^{-1}\right)\end{array}$ & $\begin{array}{l}\text { Somatic cells content } \\
\qquad\left(10^{3} \mathrm{~mL}^{-1}\right)\end{array}$ \\
\hline $2 \mathrm{H}$ & $1359 \pm 27.3$ & $1264 \pm 24.9$ & $81 \pm 1.5$ & $68 \pm 1.4$ & $66 \pm 1.4$ & $53 \pm 1.2$ & $34 \pm 0.7$ & $1504 \pm 67.7$ \\
\hline GP1 & $1441 \pm 27.1$ & $1348 \pm 23.3$ & $86 \pm 1.5$ & $72 \pm 1.5$ & $70 \pm 1.3$ & $57 \pm 1.3$ & $33 \pm 1.9$ & $1178 \pm 37.6$ \\
\hline GP2 & $1506 \pm 13.7$ & $1386 \pm 12.1$ & $88 \pm 1.0$ & $75 \pm 0.7$ & $73 \pm 0.7$ & $59 \pm 0.5$ & $36 \pm 0.8$ & $1556 \pm 158.4$ \\
\hline GP3 & $1402 \pm 18.2$ & $1307 \pm 10.0$ & $84 \pm 0.8$ & $70 \pm 1.2$ & $68 \pm 0.8$ & $54 \pm 1.0$ & $35 \pm 1.5$ & $1634 \pm 172.1$ \\
\hline GP4 & $1294 \pm 17.0$ & $1205 \pm 15.9$ & $78 \pm 1.0$ & $63 \pm 1.0$ & $63 \pm 0.8$ & $49 \pm 0.8$ & $32 \pm 1.3$ & $1560 \pm 211.0$ \\
\hline GP5 & $1235 \pm 27.2$ & $1157 \pm 25.4$ & $74 \pm 1.7$ & $63 \pm 1.7$ & $59 \pm 1.4$ & $48 \pm 1.3$ & $35 \pm 2.6$ & $1723 \pm 111.2$ \\
\hline GP6 & $1062 \pm 34.4$ & $981 \pm 30.1$ & $63 \pm 1.8$ & $52 \pm 1.9$ & $51 \pm 1.8$ & $40 \pm 1.5$ & $33 \pm 1.3$ & $1523 \pm 187.7$ \\
\hline $4 \mathrm{H}$ & $1302 \pm 23.7$ & $1228 \pm 23.6$ & $78 \pm 1.5$ & $68 \pm 1.4$ & $53 \pm 1.2$ & $63 \pm 1.2$ & $40 \pm 0.6$ & $1691 \pm 77.8$ \\
\hline GP1 & $1380 \pm 11.9$ & $1307 \pm 13.4$ & $83 \pm 1.0$ & $74 \pm 0.7$ & $67 \pm 0.5$ & $58 \pm 0.5$ & $40 \pm 1.3$ & $1686 \pm 210.2$ \\
\hline GP2 & $1380 \pm 19.2$ & $1283 \pm 20.4$ & $80 \pm 1.4$ & $73 \pm 1.2$ & $67 \pm 0.8$ & $58 \pm 0.9$ & $39 \pm 1.1$ & $1533 \pm 222.0$ \\
\hline GP3 & $1351 \pm 32.0$ & $1259 \pm 28.6$ & $80 \pm 1.9$ & $70 \pm 1.6$ & $66 \pm 1.7$ & $54 \pm 1.2$ & $40 \pm 1.5$ & $1825 \pm 148.5$ \\
\hline GP4 & $1279 \pm 36.0$ & $1193 \pm 39.5$ & $76 \pm 2.7$ & $66 \pm 2.2$ & $63 \pm 1.8$ & $51 \pm 1.8$ & $40 \pm 1.6$ & $1652 \pm 154.5$ \\
\hline GP5 & $1235 \pm 16.4$ & $1145 \pm 17.7$ & $72 \pm 1.2$ & $64 \pm 1.0$ & $59 \pm 0.6$ & $49 \pm 0.8$ & $40 \pm 2.7$ & $1494 \pm 119.4$ \\
\hline GP6 & $1015 \pm 47.7$ & $935 \pm 45.3$ & $59 \pm 2.9$ & $52 \pm 2.6$ & $49 \pm 2.4$ & $40 \pm 2.0$ & $38 \pm 3.1$ & $2053 \pm 31.5$ \\
\hline
\end{tabular}

FPCM, fat and protein corrected milk (6.5\% fat; $5.8 \%$ protein); GP, grazing period. 
(A)

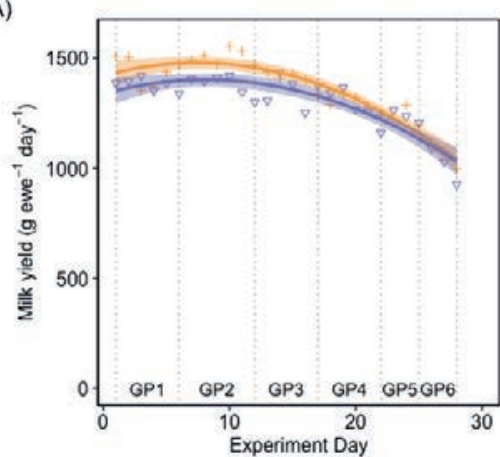

(C)

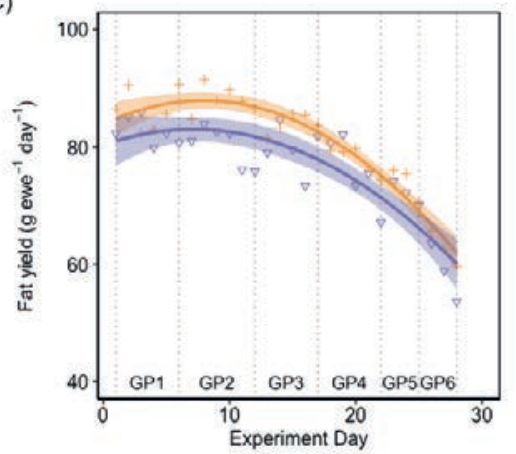

(B)

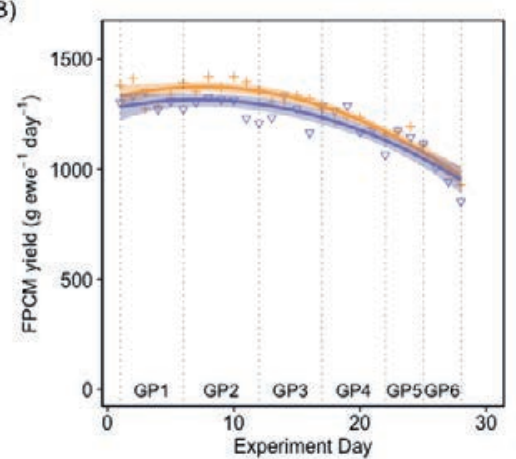

(D)

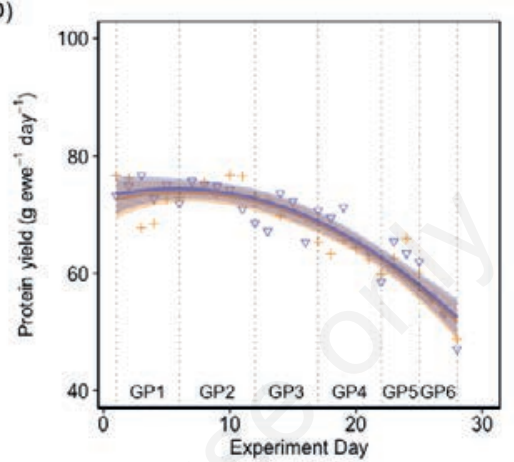

Figure 2. Best-fitting model for milk yield (A), fat and protein corrected milk (FPCM) (B), fat yield (C) and protein yield (D) of dairy ewes with two hours $(2 \mathrm{H})$ and four hours $(4 \mathrm{H})$ of access time to pasture during and experiment days. GP means grazing periods. Orange cross indicates values for $2 \mathrm{H}$ ewes' group and the violet triangle indicates values for $4 \mathrm{H}$ ewes' group. Coloured lines indicate best-fitting models and orange and violet shades indicate standard error bounds, for $2 \mathrm{H}$ and $4 \mathrm{H}$, respectively.

(A)

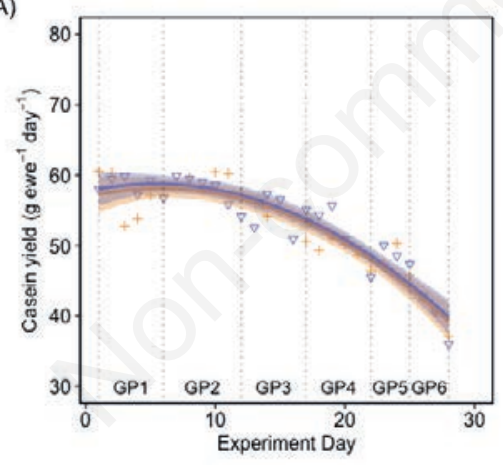

(C)

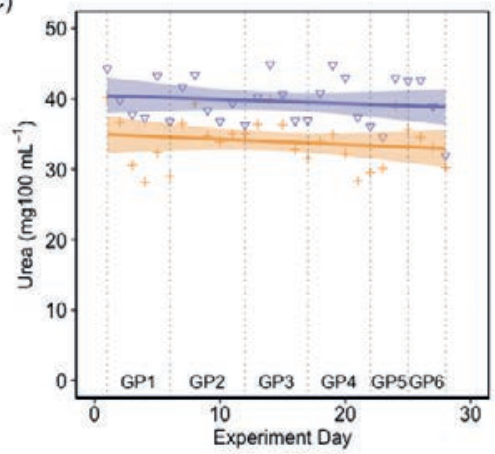

(B)

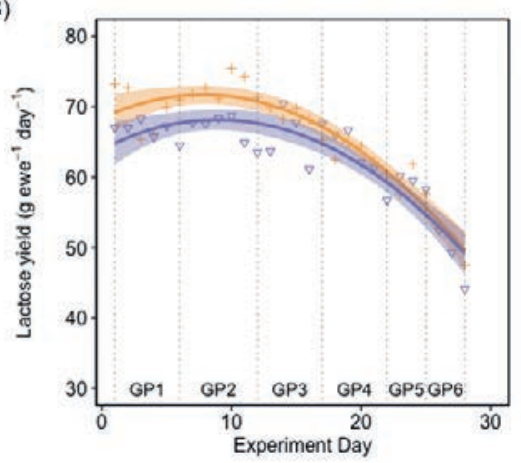

(D)

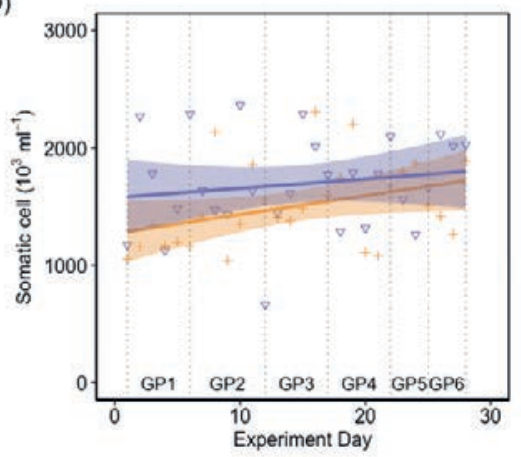

Figure 3. Best-fitting model for casein milk yield (A), lactose milk yield (B), urea milk content (C) and somatic cell milk content (D) of dairy ewes with two hours $(2 \mathrm{H})$ and four hours $(4 \mathrm{H})$ of access time to pasture and experiment days. GP means grazing periods. Orange cross indicates values for $2 \mathrm{H}$ ewes' group and the violet triangle indicates values for $4 \mathrm{H}$ ewes' group. Coloured lines indicate best-fitting models and orange and violet shades indicate standard error bounds, for $2 \mathrm{H}$ and $4 \mathrm{H}$, respectively. 


\section{Milk yield and quality}

During the experiment the average $\mathrm{FPCM}_{6.5 ; 5.8}$ yield was 1250 $\mathrm{g}_{\text {ewe }} \mathrm{e}^{-1} \mathrm{~d}^{-1}$ which was comparable with a previous study based on Sarda ewes in Mediterranean conditions (Molle et al., 2014; 2017). A similar milk yield was recorded between the two groups. In the $2 \mathrm{H}$ group, the milk yield varied from 1386 to $981 \mathrm{~g} \mathrm{FPCM} \mathrm{ewe^{-1 }}$ $\mathrm{d}^{-1}$ in GP2 and GP6, respectively. The same was observed in the $4 \mathrm{H}$ group concerning milk and lactose yields. In the $4 \mathrm{H}$ group, the values of the other performance parameters such as FPCM, protein, fat and casein yield, showed a decreasing productivity trend from GP1 to GP6 (Table 3).

The results of model fitting and treatment comparison are summarised in Table 4. All milk performance characteristics fitted significantly with a quadratic model $(\mathrm{P}<0.001)$, with the exception of urea and somatic cells. The analysis of treatment trends highlighted that there was no difference for any of the characteristics investigated between $2 \mathrm{H}$ and $4 \mathrm{H}$ (treatment trend p-value, Table 4). The linear model used for the urea and somatic cell content in milk over time, showed no significant difference between $2 \mathrm{H}$ and $4 \mathrm{H}$ $(\mathrm{P}=0.366$ and $\mathrm{P}=0.054$, for urea and somatic cells, respectively). Values of milk characteristics and best-fitted models of each treatment are shown in Figures 2 and 3, respectively.

The milk yield showed a decreasing trend during the experiment, in accordance with the lactation curve of Sarda ewes in a Mediterranean environment (Pulina et al., 2005). Milk productivity was not affected by the reduction in grazing duration from four to two hours per day, which supports our finding regarding the lack of effects on herbage intake of limiting the access time to pasture in our experimental conditions. However, this result is in contrast with the literature. Previous studies have demonstrated that the milk yield of Sarda ewes was negatively affected when daily grazing time was decreased to below four hours per day, on both grass (Molle et al., 2014) and legume-based pasture (Molle et al., 2017). Unlike the cited studies, in our experiment the higher amount of hay and concentrate supplementation in the ewes' diet seemed to reduce the required time for the daily energy intake by grazing in the spring.

\section{Grazing management and the design of sustainable mixed farming systems in Mediterranean areas}

Firstly, the exploitation of pastures by grazing ewes is one way of maintaining the diversification of traditional dairy cheeses, such as P.D.O. sheep cheeses, in order to increase the profitability of dairy sheep farms in rural and marginal areas (Pulina et al., 2018). It is also well recognised that legume-based pastures are associated with improvements in the fatty acid profile of milk and cheese (Mele, 2009).

To tackle the problem of milk prices and climate change, the intensification of livestock management based on housed ewes fed with fodder and concentrate, such as corn or wheat silage, hay and protein supplementation can lead to: i) the standardisation of milk and dairy products; and ii) an intensification of the competition between marginal and non-marginal areas, since in the latter the cost per unit of product is usually lower.

On the other hand, the abandonment of farmland in rural areas has led to an increase in wild fauna, such as wolves in some parts of Europe in the last few decades (Zingaro et al., 2018). Farmers therefore need to find solutions to protect their livestock and to limit the risk of predation. In this context, free-range grazing can no longer be considered sustainable, since intensification strategies

Table 4. Parameters of best-fitting models for milk yield and composition (shown in Figures 3) and experiment days, and treatment trend comparison of dairy ewes with two hours $(2 \mathrm{H})$ and four hours $(4 \mathrm{H})$ of access time to pasture and entire dataset.

\begin{tabular}{|c|c|c|c|c|c|c|c|c|}
\hline Model type & $\begin{array}{c}\text { Milk yield } \\
\mathbf{Q}\end{array}$ & $\begin{array}{c}\text { FPCM yield } \\
\text { Q }\end{array}$ & $\begin{array}{l}\text { Fat yield } \\
\qquad\end{array}$ & $\begin{array}{c}\text { Protein yield } \\
\text { Q }\end{array}$ & $\begin{array}{c}\text { Casein yield } \\
\mathbf{Q}\end{array}$ & $\begin{array}{c}\text { Lactose yield } \\
\text { Q }\end{array}$ & $\begin{array}{l}\text { Urea content } \\
\text { L }\end{array}$ & $\begin{array}{l}\text { Somatic cells content } \\
\text { L }\end{array}$ \\
\hline \multicolumn{9}{|l|}{$2 \mathrm{H}$ subset } \\
\hline Model P-value & $<0.001$ & $<0.001$ & $<0.001$ & $<0.001$ & $<0.001$ & $<0.001$ & 0.37 & 0.05 \\
\hline Adjusted R-squared & 0.88 & 0.90 & 0.90 & 0.84 & 0.86 & 0.88 & -0.01 & 0.10 \\
\hline Residual standard error & 50.43 & 41.52 & 2.66 & 2.96 & 2.38 & 2.45 & 3.47 & 339.30 \\
\hline Shapiro-Wilk test P-value & 0.33 & 0.99 & 0.93 & 0.93 & 0.87 & 0.27 & 0.62 & 0.09 \\
\hline \multicolumn{9}{|l|}{ 4H subset } \\
\hline Model P-value & $<0.001$ & $<0.001$ & $<0.001$ & $<0.001$ & $<0.001$ & $<0.001$ & 0.46 & 0.42 \\
\hline Adjusted R-squared & 0.80 & 0.80 & 0.77 & 0.84 & 0.88 & 0.81 & -0.02 & -0.01 \\
\hline Residual standard error & 55.74 & 55.80 & 3.86 & 2.96 & 2.22 & 2.75 & 3.39 & 413.90 \\
\hline Shapiro-Wilk test P-value & 0.17 & 0.27 & 0.13 & 0.20 & 0.12 & 0.18 & 0.15 & 0.63 \\
\hline \multicolumn{9}{|l|}{ Entire dataset } \\
\hline Model P-value & $<0.001$ & $<0.001$ & $<0.001$ & $<0.001$ & $<0.001$ & $<0.001$ & $<0.001$ & 0.07 \\
\hline Adjusted R-squared & 0.85 & 0.86 & 0.84 & 0.84 & 0.87 & 0.85 & 0.40 & 0.08 \\
\hline Residual standard error & 53.15 & 49.18 & 3.31 & 2.96 & 2.30 & 2.60 & 3.43 & 378.40 \\
\hline Shapiro-Wilk test P-value & 0.16 & 0.54 & 0.32 & 0.53 & 0.67 & 0.16 & 0.30 & 0.14 \\
\hline Factor Day P-value & $<0.001$ & $<0.001$ & $<0.001$ & $<0.001$ & $<0.001$ & $<0.001$ & 0.24 & 0.06 \\
\hline Factor Treatment P-value & $<0.001$ & $<0.001$ & $<0.001$ & 0.49 & 0.34 & $<0.001$ & $<0.001$ & 0.07 \\
\hline \multicolumn{2}{|c|}{ Factor Day*Treatment P-value 0.29} & 0.62 & 0.59 & 0.99 & 0.99 & 0.25 & 0.89 & 0.52 \\
\hline Treatment trend P-value & 0.13 & 0.42 & 0.49 & 0.97 & 0.99 & 0.10 & 0.89 & 0.52 \\
\hline
\end{tabular}

FPCM, fat and protein corrected milk; Q, quadratic model; L, linear mode. 
have been spreading among the rural areas of Mediterranean Europe e.g. through the adoption of high-yield milk ewes such as the Lacaune and Assaf breeds (Farinella, 2018). Thus, restricting access time to pasture could be a good solution to deal with predation and to ensure the diversification of dairy products, thus maintaining local sheep breeds.

Secondly, comparing past studies, all conducted on experimental farms and with few animals, with our co-conducted real farm experiment, the most evident difference concerns the feeding management. On our real farm, ewe feeding was mostly based on supplementation, such as hay and concentrate, in order to increase the milk yield and quality. This led to the identification of a shorter optimum daily grazing duration (two hours), compared to previous studies. Limiting the access time to pasture in spring should therefore be implemented with an appropriate feeding supplementation strategy aimed at reducing the labour related to grazing management and the optimisation of supplements in terms of quantity, nutritive value and frequency.

Lastly, on Mediterranean dairy sheep farms, grazing systems are usually based on artificial or semi-natural pastures characterised by a high variability in nutritive value over the seasons (Molle et al., 2008). Thus, to increase milk yield and quality, forage resources at the farm level need to be balanced between pasture and fodder during the year. Our results demonstrate that in spring, the highest quality herbage can be exploited in pastures by rotational grazing with a limited access time. This can be achieved by a high ewe stocking rate and varying rotation duration in relation to pre-grazing herbage mass and sward regrowth, favouring the consumption of the most nutritive horizon. In the Mediterranean, haymaking is concentrated in a few weeks in the spring, in April and May. In this period rotational grazing with a limited access time should thus be implemented to facilitate the production of a higher amount of high-quality fodder and reducing the labour required for grazing flock management. Moreover, thanks to the proposed grazing technique, the lactating ewes exploited the upper layer of the pasture. In this short time rotational grazing scheme, the residual herbage (less rich in nutrients) might be further exploited by non-lactating animals.

\section{Conclusions}

In semi-extensive mixed farming systems, efficient livestock management is essential to increase the environmental sustainability of dairy productions and to ensure an adequate income for rural farmers.

Dairy sheep farming is being threatened by several factors: the volatility of milk prices, predation by wild animals, and the high variability of agro-meteorological conditions, especially in the Mediterranean. On-farm research and multi-actor approaches will be crucial to develop further sustainable and resilient mixed farming systems. In the Mediterranean, in order to increase milk yield and to cope with the fluctuating availability of pasture and fodder over the years and seasons feeding strategies should be based on the exploitation of grazing resources coupled with a rational feed supplementation.

Our findings reveal that on a real sheep farm context, the productivity of a Sarda sheep flock rotationally stoked on an abundant and high-quality mixed pasture was not affected by limiting the access time to up to two hours. Our results showed that the potential ewes' herbage intake rate correlates positively with pasture quality, and a mixed pasture with a high share of legumes led to a pasture efficiency. Moreover, this case study also confirms that ewes are able to self-regulate the herbage intake and ingestion rate in relation to the pasture energy content. Finally, our on-farm study showed that the comparison between experimental and farm-level data can be useful to verify previous literature outcomes, notwithstanding the limitations derived by the up-scaling process; it can also stimulate the implementation of further studies able to address weaknesses and opportunities of dairy sheep farm management. We believe that our outcomes should encourage researchers, advisors and farmers to co-design tailored trials aimed at finding new strategies for sustainable mixed farming systems on marginal lands and to generate new knowledge through innovation projects.

\section{References}

Annicchiarico P, Ruisi P, Di Miceli G, Pecetti L, 2014. Morphophysiological and adaptive variation of Italian germplasm of sulla (Hedysarum coronarium L.). Crop Pasture Sci. 65:20613. Available from: http://dx.doi.org/10.1071/CP13342

AOAC, 1990. Official methods of analysis. Association of Official Analytical Chemists, Gaithersburg, Maryland.

Avondo M, Bordonaro S, Marletta D, Guastella AM, D'Urso G, 2002. A simple model to predict the herbage intake of grazing dairy ewes in semi-extensive Mediterranean systems. Livest. Prod. Sci. 73:275-83.

Avondo M, Bonanno A, Pagano RI, Valenti B, Grigoli A Di, Luigia Alicata M, Galofaro V, Pennisi P, 2008. Milk quality as affected by grazing time of day in Mediterranean goats. J. Dairy Res. 75:48-54.

Avondo M, Secchiari P, Battaglini LM, Bonanno A, Pulina G, 2013. Soil, pasture and animal product quality. Ital. J. Agron. 8:141-8

Baumont R, Cohen-Salmon D, Prache S, Sauvant D, 2004. A mechanistic model of intake and grazing behaviour in sheep integrating sward architecture and animal decisions. Anim. Feed Sci. Technol. 112:5-28.

Bonanno A, Di Grigoli A, Mazza F, De Pasquale C, Giosuè C, Vitale F, Alabiso M, 2016. Effects of ewes grazing sulla or ryegrass pasture for different daily durations on forage intake, milk production and fatty acid composition of cheese. Animal 10:2074-82.

Borreani G, Roggero PP, Sulas L, Valente ME, 2003. Quantifying Morphological Stage to Predict the Nutritive Value in Sulla (Hedysarum coronarium L.). Agron. J. 95:1608-17.

Charpentier A, Caillat H, Gastal F, Delagarde R, 2019a. Intake, milk production and grazing behaviour responses of strip-grazing dairy goats to daily access time to pasture and to dehydrated lucerne supplementation. Livest. Sci. 229:90-7.

Charpentier A, Caillat H, Gastal F, Delagarde R, 2019b. Intake, milk yield and grazing behaviour of strip-grazing Alpine dairy goats in response to daily pasture allowance. Animal 13:2492500 .

Conant RT, Cerri CEP, Osborne BB, Paustian K, 2017. Grassland management impacts on soil carbon stocks: A new synthesis: A. Ecol. Appl. 27:662-8.

De Renobales M, Amores G, Arranz J, Virto M, Barrón LJR, Bustamante MA, Ruiz De Gordoa JC, Nájera AI, Valdivielso I, Abilleira E, Beltrán De Heredia I, Pérez-Elortondo FJ, Ruiz R, Albisu M, Mandaluniz N, 2012. Part-time grazing improves sheep milk production and its nutritional characteristics. Food Chem. 130:90-6. 
Di Grigoli A, Todaro M, Di Miceli G, Genna V, Tornambè G, Alicata ML, Giambalvo D, Bonanno A, 2012. Effects of continuous and rotational grazing of different forage species on ewe milk production. Small Rumin. Res. 106.

Farinella D, 2018. La pastorizia sarda di fronte al mercato globale. Ristrutturazione della filiera lattiero-casearia e strategie di ancoraggio al locale. Meridiana. Riv. Stor. Sci. Soc. 93:113-34.

Garcia F, Carrère P, Soussana JF, Baumont R, 2003. The ability of sheep at different stocking rates to maintain the quality and quantity of their diet during the grazing season. J. Agric. Sci. 140:113-24.

Institut National de la Recherche Agronomique (INRA), 2010. Alimentation Des bovins, Ovins Et Caprins: Besoins Des animaux, Valeurs Des aliments, Guide pratique. Editions Quae, Versailles, France.

Lenth R, Singmann H, Love J, Buerkner P, Herve M, 2020. emmeans: estimated marginal means. R package version 1.4. 4. Am. Stat. 34:216-21.

Marley CL, Fraser MD, Fisher WJ, Forbes AB, Jones R, Moorby JM, MacRae JC, Theodorou MK, 2007. Effects of continuous or rotational grazing of two perennial ryegrass varieties on the chemical composition of the herbage and the performance of finishing lambs. Grass Forage Sci. 62:255-64.

Mele M, 2009. Designing milk fat to improve healthfulness and functional properties of dairy products: From feeding strategies to a genetic approach. Ital. J. Anim. Sci. 8:365-73.

Molle G, Decandia M, Cabiddu A, Landau SY, Cannas A, 2008. An update on the nutrition of dairy sheep grazing Mediterranean pastures. Small Rumin. Res. 77:93-112.

Molle G, Decandia M, Giovanetti V, Manca C, Acciaro M, Epifani G, Salis L, Cabiddu A, Sitzia M, Cannas A, 2017. Grazing behaviour, intake and performance of dairy ewes with restricted access time to berseem clover (Trifolium alexandrinum L.) pasture. Grass Forage Sci. 72:194-210.

Molle G, Decandia M, Giovanetti V, Manca C, Acciaro M, Epifani G, Salis L, Cabiddu A, Sitzia M, Cannas A, 2014. Effects of restricted time allocation to pasture on feeding behaviour, intake and milk production of dairy sheep rotationally grazing Italian ryegrass (Lolium multiflorum Lam) in spring. Anim. Prod. Sci. 54:1233-7.

Mottet A, de Haan C, Falcucci A, Tempio G, Opio C, Gerber P, 2017. Livestock: On our plates or eating at our table? A new analysis of the feed/food debate. Glob. Food Sec. 14:1-8.

Oteros-Rozas E, Martín-López B, Fagerholm N, Bieling C, Plieninger T, 2018. Using social media photos to explore the relation between cultural ecosystem services and landscape features across five European sites. Ecol. Indic. 94:74-86.

Penning PD, Hooper GE, 1985. An evaluation of the use of shortterm weight changes in grazing sheep for estimating herbage intake. Grass Forage Sci. 40:79-84.
Penning PD, Hooper GE, Treacher TT, 1986. The effect of herbage allowance on intake and performance of ewes suckling twin lambs. Grass Forage Sci. 41:199-208.

Peyraud JL, Taboada M, Delaby L, 2014. Integrated crop and livestock systems in Western Europe and South America: A review. Eur. J. Agron. 57:31-42.

Pinheiro J, Bates D, DebRoy S, Sarkar D, R Core Team, 2020. \{nlme\}: Linear and nonlinear mixed effects models. Available from: https://cran.r-project.org/package=nlme

Pulina G, Milán MJ, Lavín MP, Theodoridis A, Morin E, Capote J, Thomas DL, Francesconi AHD, Caja G, 2018. Invited review: Current production trends, farm structures, and economics of the dairy sheep and goat sectors. J. Dairy Sci. 101:6715-29.

Pulina G, Avondo M, Molle G, Francesconi AHD, Atzori AS, Cannas A, 2013. Models for estimating feed intake in small ruminants. Rev. Bras. Zootec. 42:675-90.

Pulina G, Macciotta N, Nudda A, 2005. Milk composition and feeding in the Italian dairy sheep. Ital. J. Anim. Sci. 4:5-14.

Sauvant D, Baumont R, Faverdin P, 1996. Development of a mechanistic model of intake and chewing activities of sheep. J. Anim. Sci. 74:2785-802.

R Core Team, 2020. R: A Language and Environment for Statistical Computing. R Foundation for Statistical Computing. Vienna, Austria. Available from: https://www.Rproject.org/

Sollenberger LE, Moore JE, Allen VG, Pedreira CGS, 2005. Reporting forage allowance in grazing experiments. Crop Sci. 45:896-900.

Valenti B, Marletta D, De Angelis A, Di Paola F, Bordonaro S, Avondo M, 2017. Herbage intake and milk yield in Comisana ewes as effect of 4 vs $7 \mathrm{~h}$ of grazing during late lactation. Trop. Anim. Health Prod. 49:989-94.

Vallebona C, Mantino A, Bonari E, 2016. Exploring the potential of perennial crops in reducing soil erosion: A GIS-based scenario analysis in southern Tuscany, Italy. Appl. Geogr. 66.

van Soest PJ, Robertson JB, Lewis BA, 1991. Polysaccharides in relation to animal nutrition. J. Dairy Sci. 74:3583-97.

Wezel A, Peeters A, 2014. Agroecology and herbivore farming systems - principles and practices. Options Méditerranéennes. Ser. A Mediterr. Semin.:753-67. Available from: http://om.ciheam. org/om/pdf/a109/a109.pdf

Yao X, Wu J, Gong X, Lang X, Wang C, Song S, Ali Ahmad A, 2019. Effects of long term fencing on biomass, coverage, density, biodiversity and nutritional values of vegetation community in an alpine meadow of the Qinghai-Tibet Plateau. Ecol. Eng. 130:80-93.

Zingaro M, Salvatori V, Vielmi L, Boitani L, 2018. Are the livestock guarding dogs where they are supposed to be? Appl. Anim. Behav. Sci. 198:89-94. 